\title{
A Study on Impact of MNREGA on Socio-Economic Status of Rural People in Dubepur Block of Sultanpur District, Uttar Pradesh, India
}

\author{
Sachchidanand Upadhyay*, Ashwani Kumar Verma, \\ Ashutosh Dwivedi, Priya Singh and Komal Yadav
}

\author{
Department of Agricultural Extension, Chandra Shekhar Azad University of \\ Agriculture and Technology, Nawabganj Kanpur-208024, India \\ *Corresponding author
}

\section{A B S T R A C T}

Keywords

MNREGA,

Participation,

Poverty and

Employment.

\section{Article Info}

Accepted:

17 October 2017

Available Online:

10 December 2017
MNREGA is a challenging programme providing employment as a social security and for poverty alleviation measure in rural areas in India. This is the revolutionary employment guarantee scheme which is considered as a right of rural citizen to work for minimum 100 days in a year, Under this programme, rainwater harvesting and desalting of canal distributaries, desalting and renovation of old ponds and digging up of new farm ponds are mainly being carried out. The Act is likely to a substantial reduction of rural-urban migration. Guaranteed employments can be a major source of empowerment for women. This act provides an opportunity to create useful assets in rural areas. Guaranteed employment is likely to change power equations in the rural society, and to foster a more equitable social order. A major part in India is facing problem of poverty and unemployment. This paper discusses advantages of MNREGA and its implementation. During this study, we emphasis to describe the impact and role of MNREGA in rural growth, and indicated for the better implementation.

\section{Introduction}

Mahatma Gandhi National Rural Employment Guarantee Act (MNREGA) is an employment guarantee scheme enacted by legislation on August 25, 2005.

Most significant fact about it is that it is considered as a right of a rural people to work for minimum 100 days in a year if he/she is willing to work and job should be provided to $\mathrm{him} / \mathrm{her}$ by authorities within a given timeframe (within 15 days) otherwise state government is liable for paying Unemployment allowance. Wages are also well defined in the scheme.

\section{Funding}

The costs of payments of wages are taken care by Central Government, $75 \%$ of material cost and also a share of administrative cost. The implementation part is done by State Governments as in many schemes. Unemployment allowance is provided by state government, so that state should take care of proper employment opportunity under this scheme. $25 \%$ of material cost is also provided by State.

One unique fact about MNREGA is that it has provided a fair opportunity to people from rural India to earn their own income without 
any discrimination of caste or gender. Most remarkable feature of MNREGA is that it pays women the same as men, something that was virtually unimaginable in rural India.

\section{Materials and Methods}

The major purpose of this chapter is to deal with various methods and procedures that are used in the selection of area, locale of study, have been discussed here as follows:

Sultanpur district is selected purposely for the study. Another cause for its selection is the close familiarity of investigator with respect to area, people, officials, etc. The five villages were selected on the randomly basis. The names of villages were collected from block office and they were arranged systematically out of only five villages were selected for the present work. The villages names of were; Pure harikant, Pakdi, Dahli Mubarakpur, Ahimane, Mohaddipur in Dubeypur Block.

After the selection of village, the respondents were selected on the random basis. Ten respondents were selected from each selected village. In this way the total no. of 50 respondents were selected for project work.

\section{Results and Discussion}

Table 1 describes the basic facilities includes electricity, and Mobile, television and toilet facilities available to households. The use of cycle, motorcycle and mobile is very common in survey area.

The study reveals that $76 \% \mathrm{SC}$ and $90 \mathrm{OBC}$ Family have electricity connection at their home. There are only $40 \%$ SC family have Television at their home. The condition of gas connection $20 \%$ SC families has gas connection in their kitchen. It is interesting to note that and less than $20 \%$ SC families have motor cycle facility. Lack of appropriate Sanitation is a major concern for the people of research area. The basic toilet and sanitation facilities are available to only $10 \%$ of households. Therefore "Swachh Bharat Abhiyan" has a role to play in survey area.

The table 2 shows that land holding of the respondents during the study investigator finds that maximum percentage $(60 \%)$ of respondents are landless while $38 \%$ respondents have up to 1 acre land size and only $2 \%$ respondents have 1 to 2 acre land holding.

The table 3 revealed that 46 respondents were earning $2000-18000$ in a year before MNREGA and 42 respondents were comes in same range of income after MNREGA while 4 respondents were earning $18001-24000$ annually before MNREGA and 6 respondents were earning the same income annually after joining MNREGA and only 2 respondents who have earning more than 24000 annual income after joining of MNREGA.

It is clear from above table 4 about the Impact of the MNREGA programme that people's income $54 \%$ respondents have given their answer to about decide the MNREGA has increased the income at somewhat and $42 \%$ respondents have told that not increased and remain same in their income and $4 \%$ respondents response that their income considerably increased.

The study shows that if the MNREGA is implemented well it can reduce poverty at the gross root level. When income of family increases, it enhances the purchasing power of rural people.

This scheme is meant for strengthening the bargaining power of unorganized workers. This is turn, could help them to struggle for other important entitlements, such as minimum wages and social security. It can empower poor people in short run. 
Table.1 Caste-wise distribution of the facilities available to respondents

\begin{tabular}{|l|l|l|l|l|}
\hline Facilities & Gen (\%) & SC (\%) & OBC (\%) \\
\hline \multirow{3}{*}{ Electricity } & Yes & 100 & 76 & 90 \\
\cline { 2 - 5 } & No & Nil & 24 & 10 \\
\hline \multirow{3}{*}{ Mobile } & Yes & 100 & 90 & 95 \\
\cline { 2 - 5 } & No & Nil & 10 & 5 \\
\hline \multirow{3}{*}{ Television } & Yes & 60 & 20 & 50 \\
\cline { 2 - 5 } & No & 40 & 80 & 50 \\
\hline \multirow{2}{*}{$\begin{array}{c}\text { Gas } \\
\text { connection }\end{array}$} & No & 98 & 40 & 80 \\
\hline \multirow{2}{*}{ Motor Cycle } & Yes & 2 & 60 & 20 \\
\cline { 2 - 5 } & Yes & 80 & 20 & 40 \\
\cline { 2 - 5 } & No & 70 & 80 & 60 \\
\hline \multirow{2}{*}{ Sanitation } & Yes & 30 & 92 & 50 \\
\cline { 2 - 5 } & No & 90 & 10 & 50 \\
\hline \multirow{2}{*}{} & & & 90 & 90 \\
\hline
\end{tabular}

Table.2 Distribution of the respondents according to size of land holding

\begin{tabular}{|c|l|c|c|}
\hline S. No. & \multicolumn{1}{|c|}{ Size of Land Holding } & No. & Respondents (\%) \\
\hline 1. & Landless & 30 & 60 \\
\hline 2. & Up to 1 Acre & 19 & 38 \\
\hline 3. & 1 to 2 Acre & 01 & 02 \\
\hline 4. & More than 2 Acre & Nil & Nil \\
\hline & Total & $\mathbf{5 0}$ & $\mathbf{1 0 0 . 0 0}$ \\
\hline
\end{tabular}

Table.3 Income variance in context of MNREGA

\begin{tabular}{|c|l|c|c|}
\hline S. No. & $\begin{array}{c}\text { Income of Respondent } \\
\text { (Annually) }\end{array}$ & Before MNREGA(No.) & After MNREGA (No.) \\
\hline 1. & Up to 18000 & 46 & 42 \\
\hline $\mathbf{2 .}$ & $18001-24000$ & 04 & 06 \\
\hline $\mathbf{4 .}$ & More than 24000 & Nil & 02 \\
\hline & Total & $\mathbf{5 0}$ & $\mathbf{5 0}$ \\
\hline
\end{tabular}

Table.4 Impact of Income by MNREGA

\begin{tabular}{|c|l|c|c|}
\hline S. No. & Statement/Item & No. & Respondents (\%) \\
\hline 1. & Considerably increased & 02 & 04 \\
\hline 2. & Increased somewhat & 27 & 54 \\
\hline 3. & Not increased \& remains same & 21 & 42 \\
\hline & Total & $\mathbf{5 0}$ & $\mathbf{1 0 0 . 0 0}$ \\
\hline
\end{tabular}


The different analysis has shows the positive impact of MNREGA on income, education, and economic upliftment in the research area.

The programme could not ensure the 100 days guarantee to the major majority of the job card holders. Most people say that the government provides low wages than market wages. Many facilities are not available at working area like as primary aids, crèche, and shade. The majority of people suggested that wages OF MNREGA should equal to market wages. Thus study observed that the performance of MNREGA is average satisfactory. During the study it was also observed, we also found short duration and temporary migration among MNREGA families. The female job card holders preferred local migration only.

\section{References}

Dr. Suman Pamecha, Indu Sharma- "SocioEconomic Impact of MGNREGA - A Study Undertaken among Beneficiaries of 20 Villages of Dungarpur District of Rajasthan"

Information from Ministry of Rural Development website, www.rural.nic.in Information from National Rural Employment Guarantee Act website, www.nrega.nic.in

\section{How to cite this article:}

Sachchidanand Upadhyay, Ashwani Kumar Verma, Ashutosh Dwivedi, Priya Singh and Komal Yadav. 2017. A Study on Impact of MNREGA on Socio-Economic Status of Rural People in Dubepur Block of Sultanpur District, Uttar Pradesh. Int.J.Curr.Microbiol.App.Sci. 6(12): 24392442. doi: https://doi.org/10.20546/ijcmas.2017.612.282 